Research Article / Araştırma Makalesi

\title{
EVALUATION OF MONETARY POLICY SHOCKS IN TURKEY: A STRUCTURAL VAR APPROACH
}

\author{
Asst. Prof. Oğuz TÜMTÜRK \\ Ordu University, Ünye FEAS, Ordu, Turkey,(oguz.tumturk@gmail.com)
}

\begin{abstract}
This paper empirically investigates the effects of monetary policy shocks on the Turkish economy using a structural VAR model. Monetary policy shocks are identified based on the non-recursive structural identification scheme. Since monetary policy stance is contingent on different funding rates in the wide interest rate corridor for the selected sample period, 2011:M1-2018:M12, this paper employs "weighted average funding cost"to represent the monetary policy stance of the CBRT. The baseline identification scheme is also extended in different ways to check the robustness of the results. The empirical results can be summarized as follows. First, Turkish data are not free from price and exchange rate puzzles. More importantly, qualitative inferences are quite persistent across different identification restrictions. Second, structural impulse-responses reveal that there is a two-way simultaneous interaction between monetary policy and exchange rate. Finally, the presence of money stock in the VAR model is redundant for identifying monetary policy shocks since the VAR models with and without money stock generate almost identical results.
\end{abstract}

Keywords: Empirical Puzzles, Monetary Policy Shock, Structural Identification.

\section{TÜRKIYE'DE PARA POLITIKASI ŞOKLARININ DEĞERLENDİRILMESİ: YAPISAL VAR YAKLAŞIMI}

\begin{abstract}
ÖZET
Bu çalışma para politikası şoklarının Türkiye ekonomisi üzerindeki etkilerini yapısal VAR modeli ile analiz etmektedir. Para politikası şokları yapısal tanımlama varsayımları ile belirlenmiştir. Çalışmanın kapsadı ̆̆ 2011:M1-2018:M12analiz döneminde faiz oranları koridoru içinde farklı fonlama oranları yer aldığından, TCMB'nin para politikası durușunu temsil etmede "ağırlıklı ortalama fonlama maliyeti” kullanılmıștır. Bununla birlikte temel tanımlama varsayımları, sonuçların tutarlılı̆̆ını test etmek için çeşitli yönlerden genişletilmiştir. Çalışmadan elde edilen sonuçlar, aşağıdaki şekilde özetlenebilir. Illk olarak, Türkiye verisi döviz kuru ve fiyat bulmacaları ortaya çıkarmaktadır. Daha da önemlisi, bu sonuçlar farklı tanımlama varsayımlarına karşı da tutarlıdır. Íkinci olarak, yapısal etki-tepki fonksiyonları, döviz kuru ve para politikası arasında iki yönlï ve eş zamanlı karşılıklı bir ilişki olduğunu göstermektedir. Son olarak, para stokunun analize dahil edildiği ve edilmediği durumlarda sonuçlar çok benzer olduğundan, para stokununun varlı̆̆ para politikası şoklarını belirlemede gereksizdir.
\end{abstract}

Anahtar Kelimeler: Ampirik Bulmacalar, Para Politikası Şokları, Yapısal Tanımlama. 


\section{Introduction}

The main focus of this paper is to explore the impacts of monetary policy shocks on key macroeconomic variables in a small open economy, Turkey. The effects of policy shocks on macroeconomic variables are a contentious issue for two reasons. First, exposing the transmission mechanism of monetary policy is not always straightforward since a large body of empirical literature often found puzzling results such as "price puzzle", "exchange rate puzzle"and "delayed overshooting" etc. Second, ifimposed identification restrictions to recover true exogenous monetary policy shocks do not have a strong economic rationale, then misidentified structural policy shocks may easily bias the results.

Dornbusch's (1976) well-known overshooting hypothesis suggests that positive innovations in domestic interest rate lead to the appreciation of exchange rate instantaneously (overshooting), and thereafter depreciates back to the uncovered interest parity (UIP). For example, Kim \& Roubini (2000) developed a structural VAR approach with non-recursive contemporaneous restrictions and concluded that the exchange rate initially appreciates in response to a contractionary monetary policy shock; but after a few months, the exchange rate depreciates over time in accordance with the UIP. Similary, Peersman \& Smets (2001), Bjørnland (2009), Kim \& Lim (2018) have documented supportive evidences for "overshooting hypothesis". On the contrary, some authors found that exchange rates appreciate significantly with a substantial delay in overshooting (delayed overshooting). Eichenbaum \& Evans (1995) indicated that nominal and real exchange rates significantly and persistently deviate from the UIP in response to a contractionary monetary policy shock. Bouakez \& Normandin (2010) concluded that the nominal exchange rate exhibits delayed overshooting in response to an expansionary monetary policy shock, and the exchange rate depreciates ten months before starting to appreciate. Similarly, Scholl \& Uhlig (2008) and Heinlein \& Krolzig (2012) have documented that positive innovations in monetary policy reveal a persistent appreciation of home currency for a prolonged period of up to 2-3 years. On the other hand, Sims (1992) and Grilli \& Roubini (1995) reported even more puzzling results: contractionary monetary policy shocks are associated with an impact depreciation in exchange rate rather than an appreciation (exchange rate puzzle), which is inconsistent with most theories.

The empirical literature also documented another anomaly, "price puzzle". Price puzzle ariseswhen domestic prices move in the wrong direction in response to a shock in monetary policy, i.e. contractionary monetary policy is followed by higher prices. According to Sims (1992), price and exchange rate puzzles may emerge for the same reason; "cost channel of interest rate". While a contractionary monetary policy raises the cost of borrowings and prices in a country, an increase in domestic prices may also cause an exchange rate depreciation. Some authors also argued that empirical anomalies may appear when monetary policy shocks are misidentified. For example, Bjornland (2009) showed that allowing for simultaneous interaction between the exchange rate and monetary policy may solve puzzling results.Similarly, Sims (1992) indicated that the price puzzle may appear when one misidentifies monetary policy shocks with a failure of including a variable that represents future inflation. For what concerns the price puzzle, Sims (1992) placed commodity prices in the information set of the monetary authority 
There are also some studies that focus on Turkey. Berument (2007) measured the monetary policy stance of the Central Bank of the Republic of Turkey (CBRT) by "spread" between the interbank interest rate and the depreciation rate of home currency and investigated the impacts of policy shocks between 1986 and 2000. He performed a VAR approach with a recursive identification scheme and concluded that positive innovations in monetary policy do not exhibit price and exchange rate puzzles. Kilinc \& Tunc (2014) employed a structural VAR approach over the period of 2006-2013. They employed the overnight interest rate as an indicator of monetary policy stance and concluded that their results are free from the exchange rate and price puzzles. Ulke \& Berument (2016) analyzed the effects of monetary policy shocks on macroeconomic variables between 1990 and 2014. Similarly, their empirical results showed no puzzling evidences in response to a shock in overnight interest rates. However, the impacts of expansionary monetary policy shocks were found to be weaker than the impacts of contractionary monetary policy shocks. Finally, Deniz (2014) employed a relatively larger size SVAR model covering the period between 2006 and 2012 with monthly data. She basically measured the impact of consumer confidence on various fundamental macroeconomic variables and concluded that domestic interest rate shock depicts no significant response on exchange rate and prices.

This paper performs a structural vector autoregressive (SVAR) approach,which is the most common approach for analyzing the effects of monetary policy in the past studies, over the period of 2011:M1-2018:M12. Before placing restrictionson the impact matrix of shocks, we need to answer following questions: i) Is there a one-way or two-way interaction between monetary policy and exchange rate? Since the literature has been indecisive about the true interaction between the exchange rate and interest rate, this question can only be answered empirically. ii) How do we properly address remaining identification restrictions in a small open economy based on the economic theory? Throughout the paper, exogenous monetary policy shocks are identified through a non-recursive structural identification scheme. Since most of the identification restrictions in the empirical literatureare often considered controversial, our identification scheme is extended with respect to alternativeidentification restrictions in line with economic theory. The baseline specification schemeis formedbased on the "simultaneity between exchange rate and monetary policy", "information delays", and "pass-through effect of exchange rates" etc.while alternative identification schemes adjust our baseline restrictions with respect to "exogenous use foreign variables", "the role of money" and Kim \& Roubini's (2000) developed identification structure.

One major issue when analyzing the impacts of monetary policy shocks in Turkey for the selected sample period is to decide which indicator of monetary policy should be employed. Even though most of the past literature have simply used a "policy rate" as an indicator of monetary policy stance, there has not been a single policy rate in Turkey since the end of 2010. The global financial turbulent in 2008-2009 deeply impacted Turkey. While the primary objective of the CBRT was to achieve price stability before the global financial crisis, the greatest lesson learnt from the crisis was the fact that ignoring financial stability may also threaten price stability. At the end of 2010, the Central Bank abandoned the old view and designed a rather unconventional monetary policy framework that aims to ensure financial stability without compromising price stability. While one-week repo rate reflects the monetary 
policy stance of the CBRT in the old conventional monetary policy, the new monetary policy framework was based on a combination of policy instruments (BIST overnight repo rate, the one-week repo rate, overnight lending/borrowing rates etc.) rather than a single benchmark policy rate. Figure 1 graphs how thepolicy rates of the CBRT evolve over the sample period. ${ }^{1}$ As seen in Figure 1, the CBRT policy rates differ from each other.So, the following question arises naturally: Which policy instrument does reflect the monetary policy stance of the CBRT? Since monetary policy stance is contingent on different funding rates through the new framework, this paper employs the weighted average funding cost (WAFC)of the bank.The WAFC simply represents the weighted average of the different policy rates, and it is realized somewhere between BIST and one-week repo rates.Overall, our paper differs from past studies in Turkey with the following aspects: i)selected indicator of monetary policy stance of the CBRT which is well-associated with our sample period ii)employedalternative identification restrictions which are consistent with economic theory.

\section{Figure 1: CBRT Policy Rates and Interest Rate Corridor (\%)}

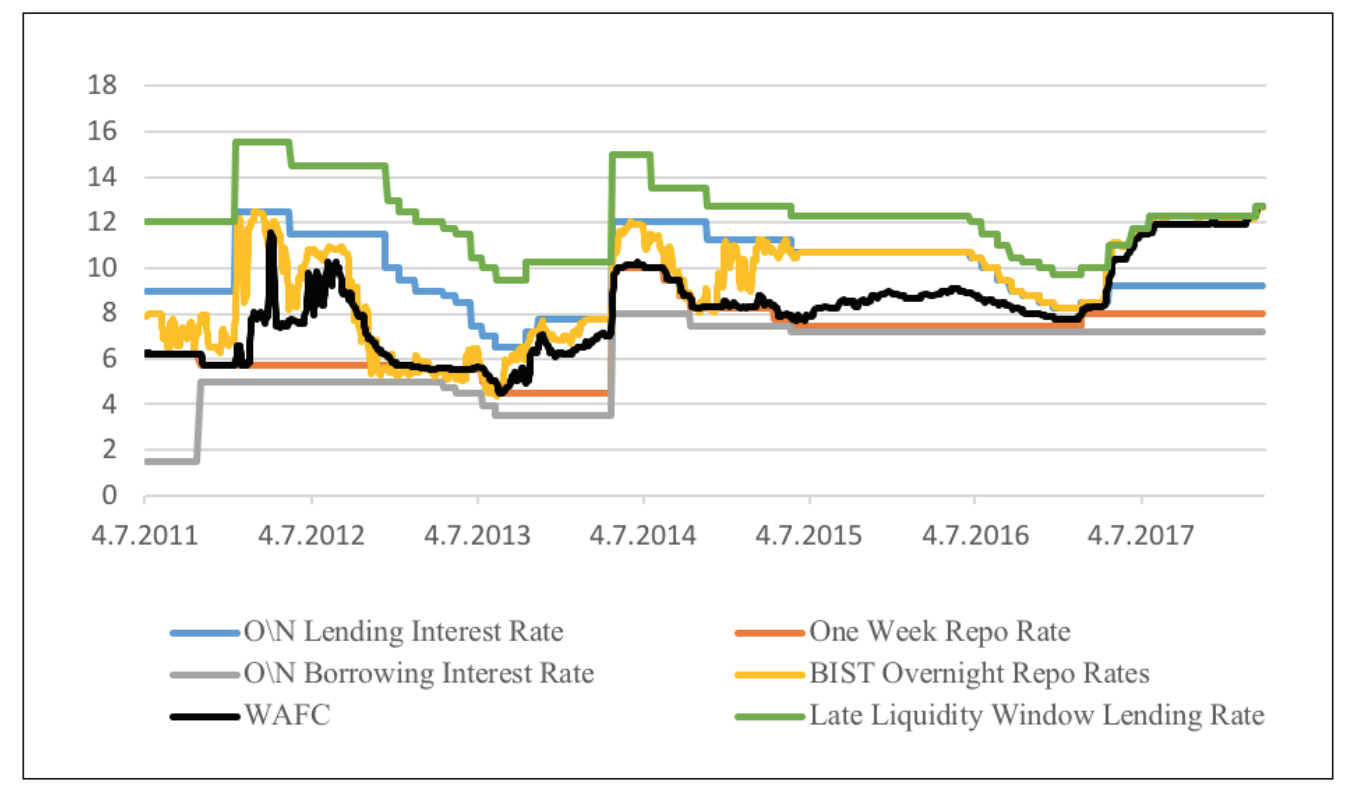

Source: CBRT

The empirical results can be summarized as follows. First, our empirical results provide evidence that the Turkish economy exhibits price and exchange rate puzzles. This also indicates that monetary transmission mechanism does not work as intended by the CBRT. There might be two explanations for the puzzles arising in Turkey; "cost channel of interest rate" and "the

1 Shortly, the overnight lending rate of the the CBRT represents the upper bound of the interest rate corridor while overnight borrowing rate forms the lower bound of the interest rate corridor. The wide gap between the upper and lower bounds is named as "interest rate corridor". 
credibility problem of the CBRT". Second, qualitative inferences about the effects of monetary policy on macroeconomic variables in Turkey are stable with respect to the choice of different identification restrictions. Third, money does not play an important role in identifying monetary policy shocks since the VAR models with and without money do not generate different results. Finally,Turkish data confirm that there is a two-way simultaneous interaction between the exchange rate and monetary policy.

The rest of this paper is organized as follows. Section 2 introduces VAR methodology used to identify monetary policy shocks while Section 3 presents identification restrictionsin detail. Section 4 provides empirical results and robustnesschecks. Finally, conclusions are drawn in Section 5.

\section{Model and Data}

A pth order unrestricted VAR model without exogenous variables has the following form:

$$
X_{t}=c+A_{1} X_{t-1}+A_{2} X_{t-2}+\cdots+A_{p} X_{t-p}+u_{t}
$$

where $\mathrm{X}_{\mathrm{t}}$ is defined as the $\mathrm{nx} 1$ vector of endogenous variables; $\mathrm{c}$ is a vector of fixed parameters, $\mathrm{p}$ is an appropriate lag order, $A_{i}$ are $n x n$ coefficient matrices, $u_{t} \sim N(0, \Sigma)$ is a $n x 1$ vector of serially uncorrelated innovations. However, if the innovations are mutually correlated i.e. the positive definite variance-covariance matrix of innovations $\Sigma$ is nondiagonal, then an exogenous shock to one of the innovations in the model also presents information about the innovations of other variables. The solution is to write the innovations $u_{t}$ as a linear transformation of mutually uncorrelated structural shocks $\varepsilon_{\mathrm{t}}$ such that:

$$
\mathrm{u}_{\mathrm{t}}=\mathrm{D} \varepsilon_{\mathrm{t}} \text { where } \mathrm{E}\left(\mathrm{u}_{\mathrm{t}} \mathrm{u}_{\mathrm{t}}^{\mathrm{T}}\right)=\Sigma=\mathrm{DD}^{\mathrm{T}}
$$

Equation (1) can be written as the following SVAR form:

$$
\mathrm{A}\left(\mathrm{X}_{\mathrm{t}}-\mathrm{c}-\mathrm{A}_{1} \mathrm{X}_{\mathrm{t}-1}-\mathrm{A}_{2} \mathrm{X}_{\mathrm{t}-2}-\ldots-\mathrm{A}_{\mathrm{p}} \mathrm{X}_{\mathrm{t}-\mathrm{p}}\right)=\mathrm{Au}_{\mathrm{t}}=\mathrm{B} \varepsilon_{\mathrm{t}} \text { where } \mathrm{D}=\mathrm{A}^{-1} \mathrm{~B}
$$

where $\mathrm{A}$ and $\mathrm{B}$ are nonsingular nxn matrices of parameters, and the matrix $\mathrm{A}$ characterizes the contemporaneous relationships among the variables in the VAR (1). All elements in matrix D are required to be identified so that one can obtain an interpretable causal impulseresponse function. In an n-variable VAR, symmetric variance-covariance matrix $\Sigma$ has $\left(n^{2}+n\right) / 2$ independent elements while $D$ has $n^{2}$ unknowns. Hence, at least $\left(n^{2}-n\right) / 2$ additional assumptions are required to achieve identification. Without these identification assumptions, the mutually uncorrelated shocks from the VAR innovations cannot be separated. In the VAR modelling with Cholesky decomposition, $\mathrm{A}$ is a lower triangular matrix with ones on the diagonal, and $\mathrm{B}$ is a diagonal matrix. Hence, Cholesky restrictions introduce lower triangular identifying assumptions. However, in the SVAR approach, A can be any structure as long as it has enough restrictions consistent with economic theory.By using structural identification, one can both allow the non-recursive structuresand place restrictions on contemporaneous structural parameters. 


\subsection{Data}

I use a 6-variable VAR model including industrial production index (OUT), consumer prices (CPI), the domestic interest rate (WAFC), real effective exchange rate (REER), world commodity price index (WCPI), and US Federal Funds rate (FFR).An increase in REER indicates an appreciation of the home currency against a broad basket of currencies. ${ }^{2} \mathrm{All}$ series, except domestic interest rate and the Federal Funds rate, are seasonally adjusted and expressed in logarithm. ${ }^{3}$ The VAR model is estimated using first-differenced stationary data since all variables are integrated of order one. ${ }^{4,5}$ The first difference of logged variables can be considered as growth rates of the original variables.The stability condition of the VAR model (1), which requires modulus of all eigenvalues are strictly less than one, ensures that impulse-responses returns back to baseline over time as structural shocks do not have a permanent impact on the differenced series. The optimum number of lagged differences of the VAR model is determined in two steps. First, the number of lags is selected by Hannan Quinn Information Criterion (HQIC). However, if the multivariate Lagrange multiplier test results suggest autocorrelation at the selected HQIC lag level, then the number of lag is increased appropriately until autocorrelation is removed. ${ }^{6}$ Exogenous deterministic components of the VAR model are also selected by HQIC.

\section{Identification}

This section identifies the exogenous monetary policy shocks through a structural identification scheme and imposes following non-recursive assumptions:

i. To reflect the features of the small open economy, the foreign variables(WCPI and FFR) enter the impact matrix of shocks above the domestic variables (OUT, CPI, WAFC, REER) in the ordering. The structure of the restrictions indicates that domestic variables cannot affect the foreign variables contemporaneously; however, domestic variables can influence them over time in line with Bjornland (2009), Kim \& Roubini (2000) developed, Barnett vd., (2016). The federal funds rate is only affected by the foreign shocksinstantaneously since domestic shocks do not have enough power to affect the policy variable of the United States. These restrictions lead to foreign variables to be contemporaneously isolated from the impacts of domestic shocks while they do not restrict foreign variables from responding with a lag to domestic shocks. This assumption will be relaxed later, and both lagged andcontemporaneous impacts of domestic shocks on foreign variables are restricted in line with Peersman \& Smets (2001). Finally, domestic variables of a small, open economy are allowedto be affected by foreign shocks contemporaneously.

2 For what concerns the price puzzle, I follow Sims (1992) and involve world commodity prices to reflect future inflation.

3 A detailed descripton of the data can be found in Appendix.

4 Phillips-Perron (1988) unit root test results are reported in Appendix.

5 See Cushman \& Zha (1997), Kim \& Roubini (2000), Peersman \& Smets (2001), Bjørnland (2009), Kim \& Lim (2018), Barnett vd. (2016), Grilli \& Roubini (1995, 1996), Bouakez \& Normandin (2010).

6 Lagrange Multiplier and normality test results can be found in Appendix. 
ii. Industrial production reacts with a delay to shocks in prices and financial variables (WAFC and REER) as a result of high adjustment costs to production. The interest rate equation is assumed to be the reaction function of the monetary authority. Monetary policy feedback rule sets the interest rate after observing the current value of exchange rates and foreign variables but not the current values of output and price level based on the assumption of "information delays" (see Sims \& Zha, 2006; Kim \& Roubini, 2000). This informational assumption indicates that the monetary authority does not have immediate access to information on output since output data is only available quarterly. Even if the domestic prices are available within the month and immediate access to information on prices is possible, this assumption is still reasonable. The argument is that the Monetary Policy Committee (MPC) does not meet each month in a year; that is, the CBRT changes the interest rates at discrete points in time.

iii. The exchange rate, being an asset price, reacts contemporaneously to all remaining structural shocks. The structure of the restrictions also refers that output and prices slowly react to the exogenous real exchange rate shocks over time due to the "pass-through process" of exchange rates.

iv. One major issue in literature when identifying exogenous monetary policy shocks is about the role of money stock.Our baseline identification restrictions are formed without domestic monetary aggregates for the following reasons. First, as pointed out by Leeper \& Rousch (2003), the stock of money has disappeared most widely used models of monetary policy since the presence of money is often associated with a decline in correlations between money stocks and economic activity. They stated that the presence of short term nominal interest rates makes money stock redundant for determining output and inflation. Second, for what concerns the liquidity puzzle, Sims (1992) advised identifying monetary policy with innovations in domestic short-term interest rates since innovations in money measures may not reflect the changes in monetary policy in the presence of money demand shocks. ${ }^{7}$ Later in Section 4.1., monetary policy shockswill be identified with moneyfor comparison.

v. While the identification restrictions above are often considered less controversial, establishing the proper interaction between financial variables is a rather contentious issue. The literature has been indecisive about the true interaction between the exchange rate and interest rate. Some authors restrict interest rate from responding contemporaneously to the exchange rate shock while the exchange rate does react to contemporaneous changes in the interest rate (see Sims,1992; Eichenbaum \& Evans,1995; Kim \& Roubini, 2000; and Peersman $\&$ Smets, 2001). On the other hand, some others switch the contemporaneous causality and restrict the exchange rate from responding contemporaneously to a monetary policy shock (see Favero \& Marcellino, 2004; Mojon \& Peersman, 2003). According to Faust \& Rogers (2003). According to Faust and Rogers (2003), open economy VAR models should identify monetary policy shocks without restricting the simultaneous responses of financial variables. Additionally, Bjornland (2009) indicated that past studies that ignore the strong simultaneous interaction between monetary policy and exchange rates through recursive zero restictions may generate biased results.

7 The liquidity puzzle arises when innovations in monetary policy fails to generate a negative correlation between the money stock and interest rate, i.e. positive innovations in monetary aggregates lead to an increase in interest rate rather than a decrease. 
This paper allows for simultaneous interaction (simultaneity) between monetary policy and exchange rate in line with Faust \& Rogers (2003) and Bjornland (2009). Since the exchange rate is an asset price, a shock on monetary policy changes expected returns, and contemporaneously affects the exchange rate. Similarly, the CBRT may immediately react to exchange rate shocks due to the fact that the exchange rate is a transmission channel of foreign shocks on domestic prices. Later, I empirically check the validity of the simultaneity assumption. Overall, our baseline identification scheme proposes the following restrictions based on the Equation (3): ${ }^{8}$

$$
\left(\begin{array}{cccccc}
1 & 0 & 0 & 0 & 0 & 0 \\
A_{21} & 1 & 0 & 0 & 0 & 0 \\
A_{31} & A_{32} & 1 & 0 & 0 & 0 \\
A_{41} & A_{42} & A_{43} & 1 & 0 & 0 \\
A_{51} & A_{52} & 0 & 0 & 1 & A_{56} \\
A_{61} & A_{62} & A_{63} & A_{64} & A_{65} & 1
\end{array}\right)\left(\begin{array}{c}
u_{\text {WCPIt }} \\
u_{F F R t} \\
u_{\text {OUTt }} \\
u_{C P I t} \\
u_{W A F C t} \\
u_{\text {REERt }}
\end{array}\right)=\left(\begin{array}{c}
\varepsilon_{W C P I t} \\
\varepsilon_{F F R t} \\
\varepsilon_{\text {OUTt }} \\
\varepsilon_{C P I t} \\
\varepsilon_{\text {WAFCt }} \\
\varepsilon_{\text {REERt }}
\end{array}\right)
$$

\section{Empirical Results}

Figure 2 reports the structural impulse-responses of the domestic variables with respect to an unexpected one-time exogenous monetary policy shock. The interest rate significantly falls in response to a monetary policy shock (i.e. expansionary monetary policy) in the very short-run, and the impact thereafterdisappears. The immediate response(when $t=0)$ is slightly negative and statistically significant. Negative innovations in domestic interestare initially associated with a statistically significant appreciation impact on the real exchange rate (exchange rate puzzle). Following the immediate appreciation, the exchange rate quickly depreciates back to baseline. Similarly, domestic prices move in the wrong direction (price puzzle) as expansionary monetary policy shock leads to a statistically significant decrease in domestic prices. Finally, an expansionary monetary policy shock slightly stimulates economic activity in line with a general indication of expansionary monetary policy stance, but the impact is statistically insignificant. Apparently, the presence of the variable WCPI which reflects future inflation as suggested by Sims (1992) fails to solve the price puzzle. Overall, non-recursive structural identification exhibits empirical anomalies, price and exchange rate puzzles in the Turkish economy. ${ }^{9}$ These results are quite striking since it provides evidence that monetary policy transmission does not work as intended by the Central Bank.

Now, one can ask the following question: What are the reasons for the puzzling results in Turkey? Or why the conducted monetary policy cannot direct the key macroeconomic variables as intended by the bank? There might be two explanations for the puzzles arising in Turkey;"cost channel of interest rate" as pointed out by Sims (1992) and "non-credible monetary policiesconducted by the CBRT". According to the cost channel of interest rates,

8 The identification assumptions among the variables are similar to Kim and Roubini (2000).

9 Since the trade linkage is much stronger between Turkey and Euro Area, the results are also controlled by using Euro Area foreign variable; Euro Area interest rate. The previous results do not change and are available upon request. 
Figure 2: Responses to Exogenous Monetary Policy Shocks

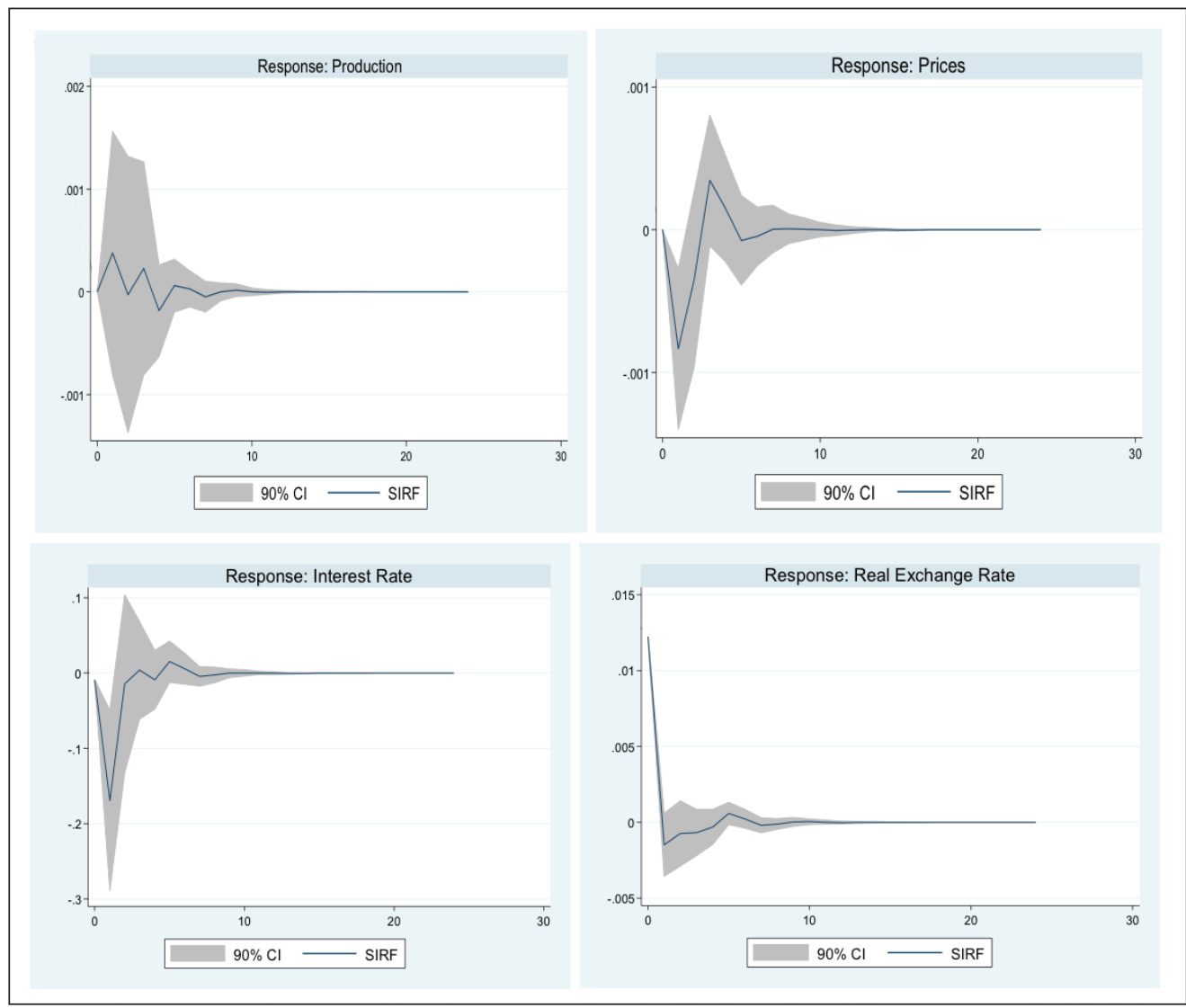

Notes: Figure 2 reports the structural impulse-responses (SIRF) of the domestic variables to a one standard deviation shock in monetary policy and 90 percent confidence intervals around point estimates (grey area). The VAR (1), which includes two lags, a linear trend and constant,satisfies the stability condition.(see Appendix for the stability test results)

an expansionary shock in monetary policymayreduce borrowing costs of firms and domestic prices in the market.Additionally, thedisinflationary pressures on domestic prices as a result of decreasing interest rates may also cause an exchange rate appreciation. The second reason is more likely to be related to the CBRT's failure on achieving credibility during the analysis period. The consistently missed target inflation rates (see Figure3)and the long-term political pressure on the CBRT for low interest rates have raised doubts about the Central Bank's independence and damaged its credibility. Therefore, agents' future expectations may have largely deviatedfrom the official commitments of the bank. 
Figure 3: CBRT Inflation Targets and Realizations (Percent)

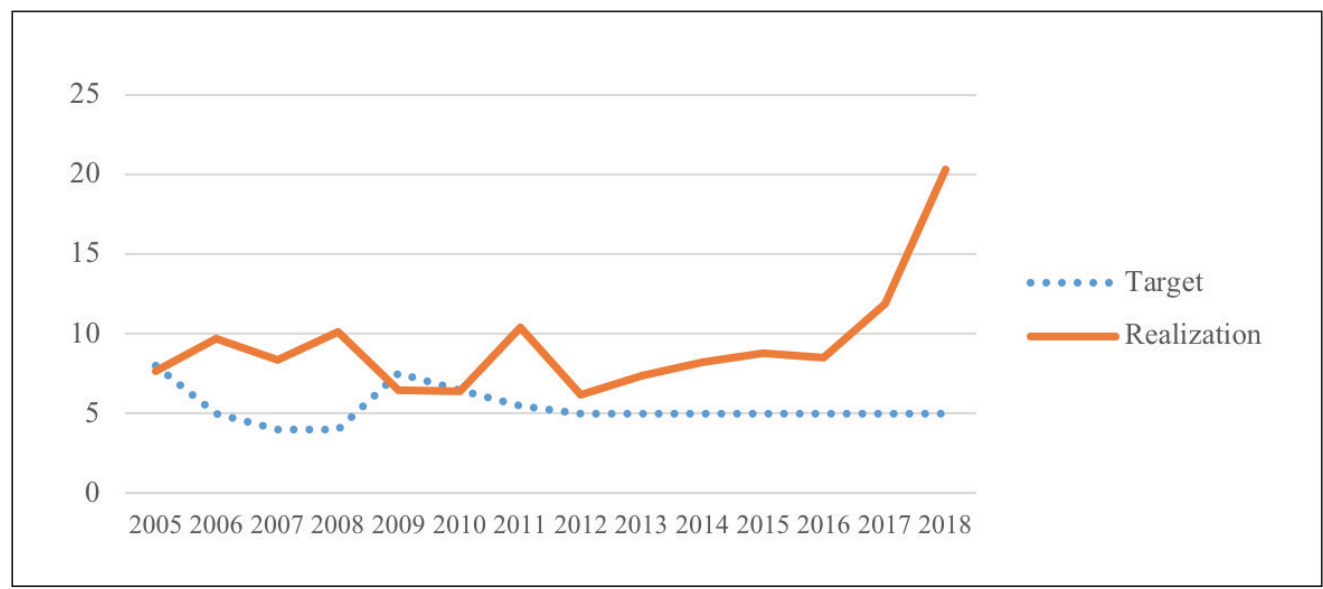

Source: CBRT

Before extending the structural identification scheme for analyzing the stability of the puzzling results, we need to find out an answer for the following question: What is the true interaction (one-way or two-way contemporaneous interactions) between the exchange rate and interest rate? To shed some light on this issue,one shouldbegin with an investigation ofCBRT's monetary policy reactionin response to innovations in the real exchange rate. As shown in Figure 2 , negative innovations in domestic interest rate lead toa contemporaneous appreciation of real exchange rate. Similarly, if the monetary policy also reacts contemporaneously to shocks in the real exchange rate, then the simultaneity assumption between financial variables is empirically justified. Figure 4 graphsthe structural impulse-responses of real exchange rate and monetary policy to an exogenous shock in the real exchange rate.The Central Bank contemporaneously reacts in response to negative innovations in exchange rate by raising interest rates and guard its currency.Consequently, the dataconfirmthat monetary policy shocks need to be identified without restricting the contemporaneous responses of the financial variables. This also explains why changing the direction of contemporaneous causation chain between exchange rate and interest rate (either $\mathrm{A}_{56}=0$ or $\mathrm{A}_{65}=0$ ) to see if this makes a difference is not a good strategy in the case of Turkey.

\subsection{Robustness of Results}

Since structural impulse-responses may be sensitive to the choice of identification restrictions, the baseline restrictions are extended in different ways for confirming the stability of results. The robustness of the results reported in this section includes following alternative identification schemes; exogenous use of foreign variables, the role of moneysupply, and Kim \& Roubini's (2000) developed identification structure. ${ }^{10}$

10 Even though the choice of the data is consistent with the literature, a large body of literature estimated their VAR models in levels rather than first differences irrespective of conventional unit root tests (see Eichenbaum and Evans, 1995; Grilli and Roubini 1995; Kim and Roubini, 2000; Peersman and Smets, 2001; Scholl and Uhlig, 2008; Barnett vd. 2016; and Kim and Lim, 2018). I also follow these studies and used all the variables in their levels. However, since the VAR estimation of the variables in levels with any selected lag level does not satisfy the VAR stability condition, I did not extend the robustness of the results with respect to alternative transformation of the data. 
Figure 4: Responses to Exogenous Exchange Rate Shocks

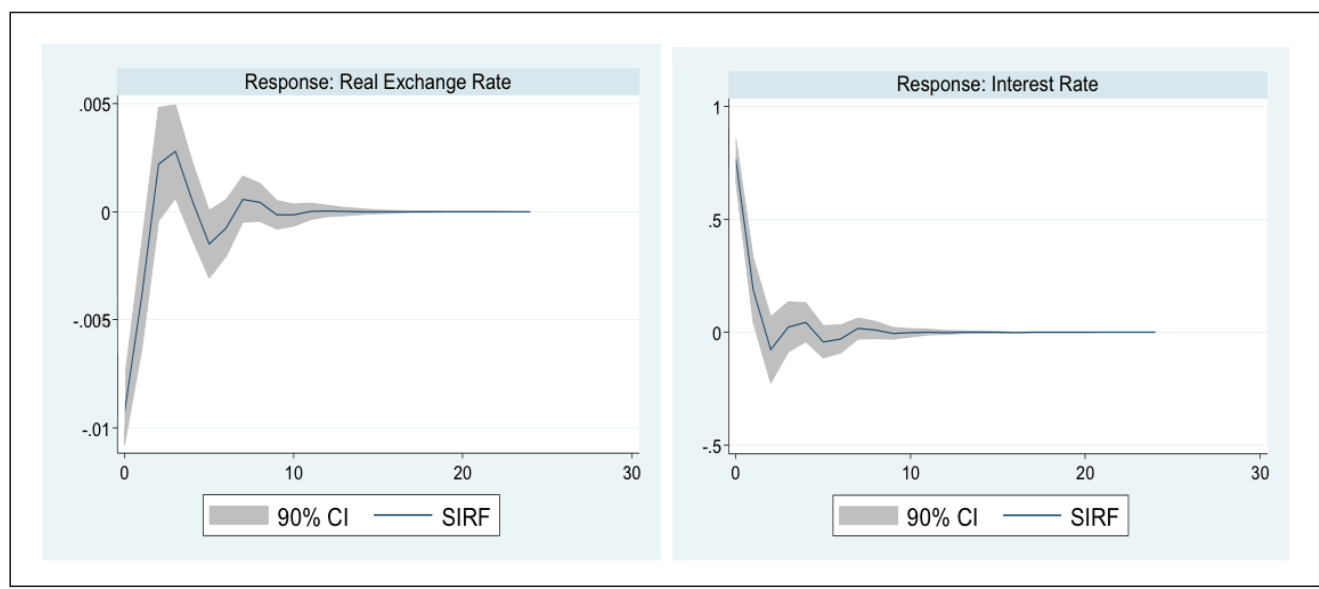

Note: Figure 4 reports the structural impulse-responses of the monetary policy and real exchange rate to a one standard deviation real exchange rate shock and 90 percent confidence intervals around point estimates (grey area).

\section{i. Exogenous Foreign Variables}

In the preceding section, the foreign variables are assumed notto be contemporaneously affected by unexpected exogenous shocks in the domestic variables. However, the baselinestructural specification (4) does not impose any restriction on the lagged responses of foreign variables to a shock in the domestic variables. Since Turkey is a small economy, domestic shocks may not be expected toimpact the foreign variableseither contemporaneously or with a lag. Now, I restrict the foreign variables from responding to the changes in domestic variables and treat them as exogenous variables. To put itmore precisely, the foreign variableshave a contemporaneous impact on the domestic variables while there is no feedback fromthe domestic variables to foreign variables. ${ }^{11}$ Overall, the new set-up of the VAR estimation includes four endogenous domestic variables (OUT, CPI, WAFC, REER) and two exogenous foreign variables (WCPI, FFR) while other assumptions remain the same.

\section{ii. The Inclusion of a New Variable, Money Stock}

In the baseline specification (4), monetary policy shocks areidentified with innovations in domestic interest rates.Now, the structural identification structure differs from the preceding section, and non-recursive identification restrictions are formed in the presence of domestic monetary aggregate, M1 mainly for two reasons. ${ }^{12}$ First,since a persuasive empirical evidencereferring the triviality of money stock when identifying monetary policy shocks has yet to be made, the empirical literature has remained cautiousabout not using monetary measures. Consequently, a large body of literature continues to identify their models with money (see

11 When performing the structural VAR analysis, no lags are assumed for the exogenous foreign variables to save the degree of freedom.

12 I also employed broad monetary aggregate, M3. Since the SVAR with M3 provides similar results compared to those obtained from narrow money supply M1, the results are only reported for M1. The results are available upon request. 
Strongin, 1995; Eichenbaum, 1992; Eichenbaum \& Evans, 1995; Christiano vd. 1996; Kim \& Roubini, 2000; Peersman \& Smets, 2001; Leeper \& Roush, 2003; Barnett vd. 2016; Kim \& Lim, 2018). Second, monetary aggregates may contain crucial information that is not provided by the domestic interest rates. Leeper \& Rousch (2003) compared the models without money and models with interactions between money and the interest rate and concluded that money stock and the interest rate jointly transmit monetary policy. Barnett vd. (2016) compared across models with and without money and indicated that models with monetary aggregates perform better than those without money. Consequently, the inclusion of monetary aggregates may be helpful in analyzing the innovations in monetary policy.

Now, the question is: How do we identify the interaction between monetary aggregate and other variables on the impact matrix of shocks? In the current set-up, the monetary aggregate equation can be interpreted as traditional money demand which responds contemporaneously to structural shocks in output, prices and domestic interest rates while other assumptions remain the same as in the baseline specification. The following equations summarize our newidentification scheme:

$$
\left(\begin{array}{ccccccc}
1 & 0 & 0 & 0 & 0 & 0 & 0 \\
B_{21} & 1 & 0 & 0 & 0 & 0 & 0 \\
B_{31} & B_{32} & 1 & 0 & 0 & 0 & 0 \\
B_{41} & B_{42} & B_{43} & 1 & 0 & 0 & 0 \\
B_{51} & B_{52} & 0 & 0 & 1 & B_{56} & B_{57} \\
B_{61} & B_{62} & B_{63} & B_{64} & B_{65} & 1 & 0 \\
B_{71} & B_{72} & B_{73} & A_{74} & A_{75} & B_{76} & 1
\end{array}\right)\left(\begin{array}{c}
u_{W C P I_{t}} \\
u_{F F R_{t}} \\
u_{O U T_{t}} \\
u_{C P I_{t}} \\
u_{W A F C_{t}} \\
u_{M 1_{t}} \\
u_{R E E R_{t}}
\end{array}\right)=\left(\begin{array}{c}
\varepsilon_{W C P I_{t}} \\
\varepsilon_{F F R_{t}} \\
\varepsilon_{O U T_{t}} \\
\varepsilon_{C P I_{t}} \\
\varepsilon_{W A F C_{t}} \\
\varepsilon_{M 1_{t}} \\
\varepsilon_{R E E R_{t}}
\end{array}\right)
$$

\section{iii. Interaction Between Foreign Shocks and Domestic Variables (Kim and Roubini's Specification)}

When identfying monetary policy shocks in the baseline identification scheme (4), domestic variables are assumed to be contemporaneously affected by foreign shocks. However, some authors (see Kim \& Roubini, 2000; Barnett vd., 2016) place contemporaneous restrictions on the domestic variables response with respect to innovations in foreign variables. Now, I follow the same non-recursive identification assumptions among the variables as suggested by Kim and Roubini and assume .

Figure 5 graphs the structural impulse-responses of the domestic variables obtained from the alternative identification schemes with respect to a one standard deviation exogenous monetary policy shock. Even though there exist some minor quantitative differences among the structural impulse-responses, reactions of the variables are qualitatively quite similar to what was found in the baseline specification. That is, the puzzling outcomes in Turkish data are quite persistent with respect to alternative identification restrictions. Additionally, since the appearance of money in the VAR model (1) does not differ the results, one can conclude that the presence of money stock in the VAR model is redundant for analyzing monetary policy shocks. 
Figure 5: Alternative and Baseline Identification Schemes, Responses to Exogenous Monetary Policy Shocks

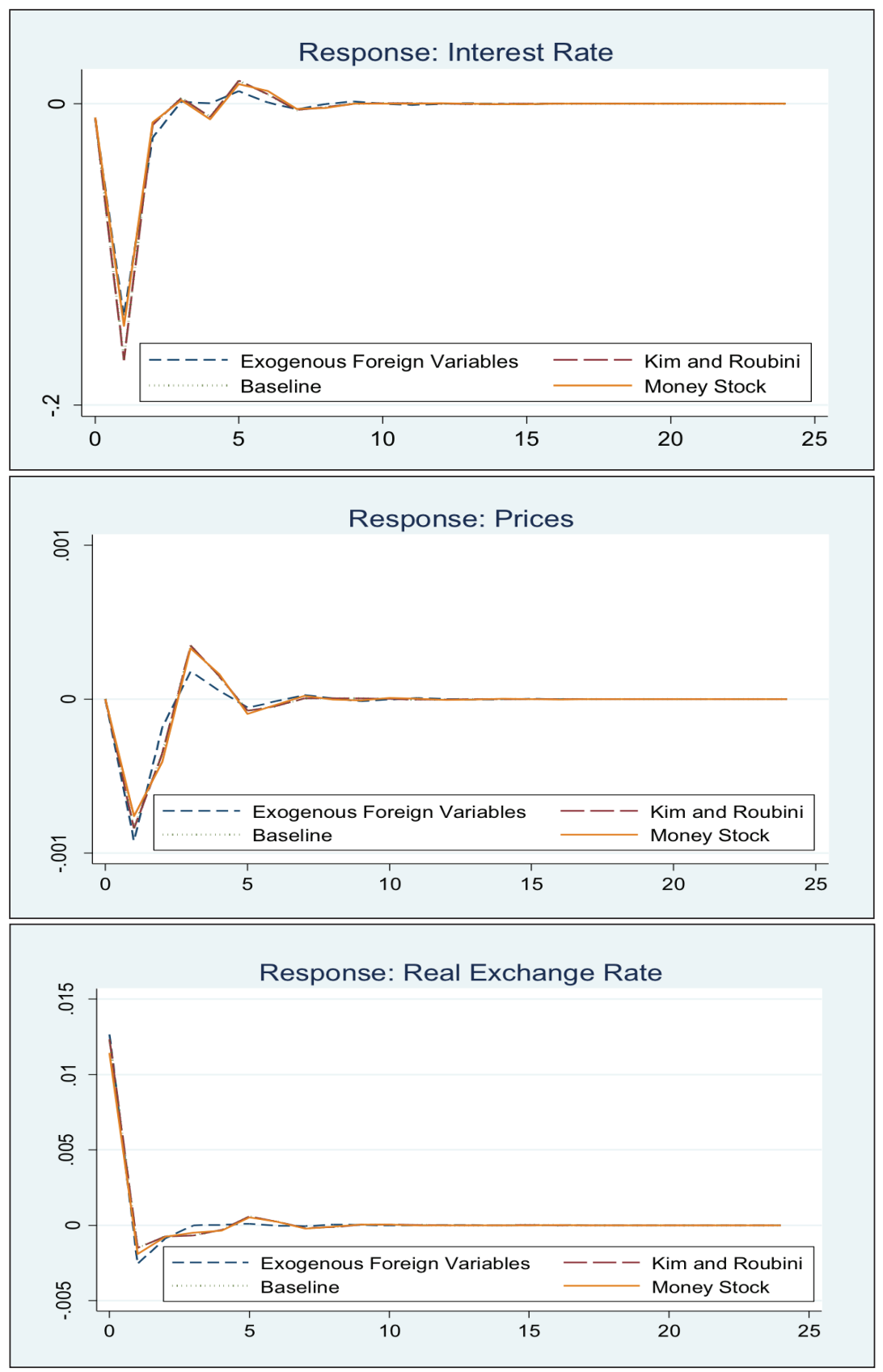

Notes: Figure 5 reports the structural impulse-responses of the endogenous variables to a one standard deviation shock in monetary policy and 90 percent confidence intervals around point estimates (grey area). All VAR models satisfy the stability condition. 


\section{Conclusion}

The main purpose of this paper is to explore the impacts of a monetary policy shock in a small open economy, Turkey. This paper employs the weighted average funding cost of the CBRT since the monetary policy framework was based on a combination of policy instruments rather than a single benchmark policy rate for the selected sample period, 2011:M1-2018:M12. The major challenge when analyzing the impacts of monetary policy shocks through a VAR model is to decide how to properly address identification restrictions in a small open economy based on the economic theory. When performing a VAR analysis, exogenous monetary policy shocks are identified through the non-recursive structural identification scheme. Since structural impulse-responses may be sensitive to the choice of identification restrictions, baseline restrictions are also extended in different ways for confirming the stability of results. Throughout the paper, restrictions on the impact matrix of shocks are mainly motivated by the following notions: "informational delays", "simultaneity assumption", "the role of money", "pass-through effect of exchange rate", "endogenous and exogenous use of foreign variables" etc. The main results can be summarized as follows:

i. The empirical results reveal that Turkish data exhibit well-known price and the exchange rate puzzles. More importantly, qualitative inferences about the effects of monetary policy in Turkey are quite persistent across different identification restrictions. The presence of the empirical anomalies in the Turkish economy suggests that the transmission mechanism of monetary policy does not work properly.

ii. The empirical evidencesalso show that the data confirm thesimultaneity between financial variables. This is quite reasonable since the CBRT may immediately reacts to exchange rate shocks due to the fact that the exchange rate is a transmission channel of foreign shocks on domestic prices. Also, since the exchange rate is an asset price, a shock on monetary policy may change expected returns, and contemporaneously affectthe exchange rate.

iii.Since whether monetary aggregates play an important role in identifying exogenous monetary policy shocks is another controversial issue, the VAR analyses is also performed with money for comparison. The inclusion of money in the VAR analysis does not differ the puzzling results; therefore, the presence of money seems redundant for identifying monetary policy shocks in Turkey.

iv. There might be two explanations for puzzling results in Turkey. First, the cost channel of monetary policy innovations may explain both the price and exchange rate puzzles. That is, the positive innovations in the interest rate that generates disinflationary pressures on domestic prices may also cause an exchange rate appreciation. Second, why such puzzling outcomes are observed as a response to monetary policy shocks is also likely to be related to lack of "monetary policy credibility". Since the CBRT's failure on achieving the target inflation rates and the long-term political pressure on the CBRT for low interest rates havehit the banks' credibility, agents' future expectations may not coincide with the official commitments of the bank. 


\section{References}

Barnett, W. A., Bhadury, S. S., \& Ghosh, T. (2016). An SVAR approach to evaluation of monetary policy in India: Solution to the exchange rate puzzles in an open economy. Open Economies Review, 27(5), 871-893.

Berument, H. (2007). Measuring monetary policy for a small open economy: Turkey. Journal of Macroeconomics, 29(2), 411-430.

Bjørnland, H. C. (2009). Monetary policy and exchange rate overshooting: Dornbusch was right after all. Journal of International Economics, 79, 64-77.

Bouakez, H., \& Normandin, M. (2010). Fluctuations in the foreign exchange market: How important are monetary policy shocks. Journal of International Economics, 81(1),139-153.

Christiano, L. J., Eichenbaum, M., \& Evans, C.L. (1996). The effects of monetary policy shocks: Evidence from the flow of funds. Review of Economics and Statistics, 78, 16-34.

Deniz, P. (2014). Consumer confidence in dynamic stochastic general equilibrium model (Doctoral Dissertation). Marmara Üniversitesi, İstanbul.

Dornbusch, R. (1976). Expectations and exchange rate dynamics. Journal of Political Economy, 84, 11611176.

Eichenbaum, M. (1992). Interpreting the macroeconomic time series facts: The effects of monetary policy. European Economic Review, 36(5), 1001-1011.

Eichenbaum, M., \& Evans, C. (1995). Some empirical evidence on the effects of shocks to monetary policy on exchange rates. Quarterly Journal of Economics, 110, 975-1010.

Faust, J., \& Rogers, J. H. (2003). Monetary policy's role in exchange rate behavior. Journal of Monetary Economics, 50, 1403-1622.

Favero, C. A., \& Marcellino, M. (2004). Large datasets, small models and monetary policy in Europe. Bocconi University.

Grilli, V., \& Roubini, N. (1995). Liquidity and exchange rates: Puzzling evidence from the G-7 countries. Working Papers 95-17, New York University, Leonard N. Stern School of Business, Department of Economics.

Heinlein, R., \& Krolzig, H-M. (2012). Effects of monetary policy on the US Dollar/UK pound Exchange rate. Is there a "delayed overshooting puzzle? Review of International Economics, 20(3), 443-467.

Kilinc, M., \& Tunc, C. (2014). Identification of monetary policy shocks in Turkey: A structural VAR approach. Working Paper No. 1423, Research and Monetary Policy Department, Central Bank of the Republic of Turkey.

Kim, S., \& Lim, K. (2018). Effects of monetary policy shocks on exchange rate in small open Economies. Journal of Macroeconomics, 56, 324-339.

Kim, S., \& Roubini, N. (2000). Exchange rate anomalies in the industrial countries: A solution with a structural VAR approach. Journal of Monetary Economics, 45, 561-586.

Leeper, E., \& Roush, J. (2003). Putting 'M' back in monetary policy. Journal of Money, Credit and Banking, 35(6), 1217-1256.

Mojon, B., \& Peersman, G. (2003). AVAR description of the effects of monetary policy in the individual countries of the Euro area. In I. Angeloni, A. Kashyap, B. Mojon (Eds.), Monetary Policy Transmission in the Euro Area, Part I. (pp. 56-74), Cambridge: Cambridge University Press.

Peersman, G., \& Smets, F. (2001). The monetary transmission mechanism in the Euro Area: More evidence from VAR analysis. Working Paper No:91, European Central Park.

Scholl, A., \& Uhlig, H. (2008). New evidence on the puzzles: Results from agnostic identification on monetary policy and exchange rates. Journal of International Economics, 76, 1-13. 
Sims, C. A. (1992). Interpreting the macroeconomic time series facts: The effects of monetary policy. European Economic Review, 36, 975-1011.

Sims, C. A., \& Zha, T. (2006). Does monetary policy generate recessions? Macroeconomic Dynamics, 10(02), 231-272.

Strongin, S. (1995). The identification of monetary policy disturbances: Explaining the liquidity puzzle. Journal of Monetary Economics, 34, 463-497.

Ulke, V., \& Berument, M. H. (2016). Asymmetric effects of monetary policy shocks on economic performance: Empirical evidence from Turkey. Applied Economics Letters, 23(5), 353-360.

\section{APPENDIX}

\section{Description of Data and Sources:}

OUT: Industry Production Index for Turkey (PROD) $(2015=100)$, seasonally adjusted by official source and expressed in logs. PROD data is obtained from the Federal Reserve Bank of St. Louis (FRED)

CPI:Consumer Price Index for Turkey $(2015=100)$, seasonally adjusted by Holt-Winters and expressed in logs. CPI data is obtained from the CBRT's Electronic Data Delivery System (EDDS).

WAFC:The Weighted Average Funding Cost of the CBRT (\%). WAFC data is obtained from EDDS.

M1: M1Money Supply, seasonally adjusted by official source and expressed in logs. M1 data is obtained from FRED.

REER: Real Effective Exchange Rate for Turkey (2015=100), seasonally adjusted by Holt-Winters and expressed in logs. The exchange rate is specified so that an increase implies appreciation of home currency. REER data is obtained from FRED.

WCPI:World Commodity Price Index, seasonally adjusted by Holt-Winters and expressed in logs. WCPI data is obtained from FRED.

FFR: Federal Funds Rate (\%). FFR data is obtained from FRED.

Table A1: Phillips-Perron Unit Root Test Results

\begin{tabular}{cccc}
\hline & Level $(\mathbf{5 \%}$ Critical Value) & First Difference (5\% Critical Value) & Result \\
\hline OUT & $-3.722(-4.051)^{\mathrm{a}}$ & $-16.335(-2.895)$ & $\mathrm{I}(1)$ \\
\hline CPI & $-0.176(-3.455)$ & $-7.142(-2.895)$ & $\mathrm{I}(1)$ \\
\hline WAFC & $0.207(-3.455)$ & $-8.076(-2.895)$ & $\mathrm{I}(1)$ \\
\hline REER & $-2.502(-3.455)$ & $-9.809(-2.895)$ & $\mathrm{I}(1)$ \\
\hline M1 & $-3.272((-3.455)$ & $-10.676(-2.895)$ & $\mathrm{I}(1)$ \\
\hline WCPI & $-1.684(-3.455)$ & $-7.293(-2.895)$ & $\mathrm{I}(1)$ \\
\hline FFR & $2.057(-3.455)$ & $-6.776(-2.895)$ & $\mathrm{I}(1)$ \\
\hline
\end{tabular}

Notes: Phillips-Perron (1988) unit root test is performed to investigate the stationarity properties of the variables. The test uses Newey-West heteroscedasticity and autocorrelation consistent (HAC) covariance estimator. Newey-West lag truncation parameter is three. When testing a variable in level, both a constant and a time trend are included. When testing a variable in first differences, only a constant is included. ${ }^{\text {a }}$ ) represents $\% 1$ critical value. 
Table A2: Eigenvalue Stability Condition

\begin{tabular}{cc}
\hline Eigenvalue & Modulus \\
\hline$-.1453839+.6010096 \mathrm{i}$ & .618344 \\
\hline$-.1453839+.6010096 \mathrm{i}$ & .618344 \\
\hline $.1772636+.5731993 \mathrm{i}$ & .599983 \\
\hline $.1772636+.5731993 \mathrm{i}$ & .599983 \\
\hline$-.2187352+.4164474 \mathrm{i}$ & .470397 \\
\hline$-.2187352+.4164474 \mathrm{i}$ & .470397 \\
\hline $.2504592+.3719247 \mathrm{i}$ & .448395 \\
\hline $.2504592+.3719247 \mathrm{i}$ & .448395 \\
\hline$-.2536334+.1805443 \mathrm{i}$ & .31133 \\
\hline$-.2536334+.1805443 \mathrm{i}$ & .31133 \\
\hline $.08696734+.2183258 \mathrm{i}$ & .235009 \\
\hline $.08696734+.2183258 \mathrm{i}$ & .235009 \\
\hline
\end{tabular}

Note: Since all the eigenvalues lie inside the unit circle, VAR satisfies the stability condition.

Table A3: Lagrange Multiplier and Normality Test Results

\begin{tabular}{cccc}
\hline \multicolumn{2}{c}{ VAR Order $^{(\mathbf{a})}$} & & \multicolumn{2}{c}{ Jarque-Bera Normality Test $^{(\mathbf{b})}$} \\
\hline Lag 1 & Lag 2 & Equation & Prob. Value $^{\text {1 }}$ \\
\hline 61.051 & $40.042^{*}$ & WCPI & .905 \\
\hline$(0.0056)$ & $(0.295)$ & FFR & .000 \\
\hline & & OUT & .000 \\
\cline { 2 - 4 } & & CPI & .285 \\
\cline { 2 - 4 } & & WAFC & .366 \\
\cline { 2 - 4 } & & REER & .664 \\
\hline
\end{tabular}

Notes: ${ }^{a}$ An asterisk indicates the VAR order chosen. A large enough value is assigned on $\mathrm{p}$ so that $\mathrm{u}_{\mathrm{t}}$ is free from autocorrelation. The null of multivariate LM autocorrelation test indicates that there is no first order autocorrelation. As a result, the VAR model (1) includes two lags.

${ }^{\text {b }}$ Majority of the Jarque-Bera normality tests do not reject the null of normality. 